\title{
Christian Stempel
}

\section{Treu und Glauben im Unionsprivatrecht}

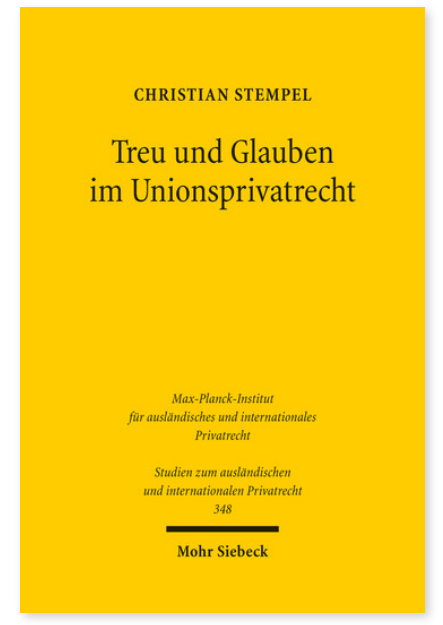

2016. XVII, 349 Seiten. StudIPR 348

ISBN 978-3-16-154420-0

DOI 10.1628/978-3-16-154420-0

eBook PDF 79,00€

ISBN 978-3-16-154350-0

fadengeheftete Broschur 79,00€
Es gibt im Unionsprivatrecht wenige Begriffe, die über den einzelnen Rechtsakt hinaus von so großer Bedeutung und zugleich so wenig übergreifend und systematisierend erforscht sind wie Treu und Glauben. Dies mag daran liegen, dass man es mit einem in Anwendungsbereich, Inhalt und Rechtsfolgen höchst unbestimmten Grundsatz im Umfeld einer fragmentarischen Rechtsmaterie zu tun hat. Eine nationalrechtliche Vorprägung ist zwar durchgehend vorhanden, fällt jedoch unterschiedlich aus. Christian Stempel untersucht, wie sich vor diesem Hintergrund ein einheitliches Verständnis des unionsprivatrechtlichen Grundsatzes von Treu und Glauben entwickeln kann, der mittlerweile vom Unionsgesetzgeber und auch vom Europäischen Gerichtshof häufig verwendet wird. Er zeigt vorhandene Entwicklungen und Missstände auf, eröffnet aber auch Perspektiven für eine transparentere, einheitlichere und systematischere Handhabung des Grundsatzes auf unionaler wie auf nationaler Ebene.

Christian Stempel Geboren 1982; Studium der Rechtswissenschaften in Köln, Paris (Maîtrise en Droit) und Cambridge (LL.M.); Assistent am Max-Planck-Institut für ausländisches und internationales Privatecht in Hamburg; seit 2014 Referent beim Bundeskartellamt.

\section{Jetzt bestellen:}

https://mohrsiebeck.com/buch/treu-und-glauben-im-unionsprivatrecht-9783161544200?no_cache=1 order@mohrsiebeck.com

Telefon: $+49(0) 7071-923-17$

Telefax: +49 (0)7071-51104 